December 2016

\title{
The New Push for Assisted Suicide
}

Dennis Sullivan

Cedarville University

Follow this and additional works at: http:// digitalcommons.cedarville.edu/

bioethics_in_faith_and_practice

Part of the Bioethics and Medical Ethics Commons

DigitalCommons@Cedarville provides a publication platform for fully open access journals, which means that all articles are available on the Internet to all users immediately upon publication. However, the opinions and sentiments expressed by the authors of articles published in our journals do not necessarily indicate the endorsement or reflect the views of DigitalCommons@Cedarville, the Centennial Library, or Cedarville University and its employees. The authors are solely responsible for the content of their work. Please address questions to dc@cedarville.edu.

\section{Recommended Citation}

Sullivan, Dennis (2016) "The New Push for Assisted Suicide," Bioethics in Faith and Practice: Vol. 2 : No. 1 , Article 2. DOI: $10.15385 /$ jbfp.2016.2.1.2

Available at: http://digitalcommons.cedarville.edu/bioethics_in_faith_and_practice/vol2/iss1/2 


\section{The New Push for Assisted Suicide}

Browse the contents of this issue of Bioethics in Faith and Practice.

Please read the Senior Editor's Preview for his insight about this article.

About the Author(s)

Dr. Dennis Sullivan is Professor of Pharmacy Practice and Director of the Center for Bioethics at Cedarville University.

Institution/Affiliation

Cedarville University

\section{Abstract}

The new push to legalize physician assisted suicide is a bad idea. It violates the Hippocratic tradition, dating back 2400 years. It impairs the trust relationship between doctor and patients, and would detract from modern efforts to improve palliative care and hospice. Finally, it is contrary to clear principles from the God's Word.

\section{Keywords}

Assisted suicide, end of life, aid in dying

\section{Creative Commons License} (c) (1) (3)

This work is licensed under a Creative Commons Attribution-Noncommercial-No Derivative Works 4.0 License. 


\title{
From the Senior Editor
}

\section{The New Push for Assisted Suicide}

\author{
Dennis M. Sullivan, M.D., M.A. (Ethics) \\ Cedarville University
}

There is a growing movement within the American Medical Association (AMA) to legalize "aid in dying," otherwise known as physician-assisted suicide. The current ethics statement of the AMA, with roots going back thousands of years, states the following:

1) Physician assisted suicide is fundamentally inconsistent with the physician's professional role.

2) It is critical that the medical profession redouble its efforts to ensure that dying patients are provided optimal treatment for their pain and other discomfort.

3) Physicians must resist the natural tendency to withdraw physically and emotionally from their terminally ill patients.

4) Requests for physician assisted suicide should be a signal to the physician that the patient's needs are unmet... i

Now this commonsense, compassionate standard is giving way to something more radical. At its meeting last June, the AMA's Council for Ethical and Judicial Affairs approved the study of "aid in dying," prior to its next annual meeting in 2017. The stated goal is to consider going "neutral" on assisted suicide. This would be an historical departure for the AMA.

There are many reasons this is a bad idea. It impairs the trust relationship between a doctor and her patients. It would detract from modern efforts to improve palliative care and hospice. And given our utilitarian society that so devalues the sanctity of life, a "right to die" could easily morph into a "duty to die."

From a Christian perspective, the new push for physicians to help their patients kill themselves is an affront to two vital biblical principles: the sanctity of life and the sovereignty of God. Psalm 8:5 affirms, "You have made him [Man] a little lower than the heavenly beings, and crowned him with glory and honor." Psalm 139 amplifies the high value of each one of us, when David declares, "I praise you, for I am fearfully and wonderfully made" (v. 14). Scripture clearly tells us that human persons have inestimable valuable in God's sight.

And this Christian anthropology is reinforced by further biblical teaching that God alone is Sovereign over life and death, not us. We must all remember that God is the Author of all life. Death is the curse brought about by Adam's sin in Genesis 3:17-19. Therefore, we must celebrate the gift of life, and not seek death.

No, death is not our friend, even for the seriously ill. In fact, death is the ultimate enemy, brought about by the fall. But Christians need not fear death, for death has been conquered through Christ. The apostle Paul wrote, "Death is swallowed up in victory" (1 Cor. 15:54).

Bioethics in Faith and Practice vol. 2, no. 1, pp. 1-3. ISSN 2374-1597

(C) 2016, Dennis Sullivan, licensed under CC BY-NC-ND

(http://creativecommons.org/licenses/by-nc-nd/4.0/ ) 
Life is a gift of God, and is worth living. The impulse for assisted suicide should give way to a renewed emphasis on hospice and palliative care for the terminally ill, and for the church to come alongside to help all of us who are suffering under the curse of sin and death.

In short, physician assisted suicide is bad medicine, and we should oppose it.

i Physician Assisted Suicide H-140.952. American Medical Association Ethics Policy. 1993 (revised 2009).

Available at: https://www.ama-assn.org/. 


\section{Bibliography}

${ }^{1}$ Physician Assisted Suicide H-140.952. American Medical Association Ethics Policy. 1993 (revised 2009). Available at: https://www.ama-assn.org/.

Crossway Bibles. 2007. ESV: Study Bible : English Standard Version. Wheaton, Ill: Crossway Bible 